\title{
Risk of hepatitis B virus-related hepatocellular carcinoma development is much higher in Koreans than in Taiwanese
}

Jae-Jun Shim, Jung Wook Kim, and Byung-Ho Kim

Department of Internal Medicine, Kyung Hee University School of Medicine, Seoul, Korea

Received: May 25, 2016 Accepted: November 21, 2016

\section{Correspondence to}

Byung-Ho Kim, M.D.

Department of Internal Medicine, Kyung Hee University School of Medicine, 23 Kyungheedae-ro, Dongdaemun-gu, Seoul 02447, Korea

Tel: +82-2-958-8145

Fax: +82-2-968-1848

E-mail: kimbh1955@gmail.com
Hepatocellular carcinoma (HCC) caused by chronic hepatitis B virus (HBV) infection is a major health problem in Asian people [1]. We herein report an interesting finding that large difference exists even between two Asian countries in terms of HBV-related HCC occurrence. We found that incidence of HBV-related HCCs is more than twice in Koreans than in Taiwanese in spite of similar risk factors between two countries.

Using data from large-scale surveys of HCC incidence and viral hepatitis prevalence, we calculated the incidence of HBV-related HCC in the two countries [2]. In total, 798,125 Korean people (40 to 79 years of age) were hepatitis B surface antigen (HBsAg)-positive in 2005, and 10,456 HCCs were recorded in the same age group. Among them, 7,560 (72.3\%) were HBV-related HCCs. The annual incidence of HCC was 947 per 100,000 persons with HBV infection (Fig. 1). This was equivalent to one HCC occurrence for every 106 persons with HBV infection per year. From 2005 to 2011, the annual incidence of HBV-related HCC in Korea did not change; the average incidence was 906 per 100,000 persons with HBV infection (0.91\%) year). In Taiwan, 1,096,944 persons (40 to 79 years of age) were HBsAg-positive in 2002, and 6,390 new HCC cases were reported in the same age group. Among them, 4,147 (64.9\%) were HBV-related HCCs. The annual incidence was 378 per 100,000 persons with HBV infection in Taiwan (Supplementary Table 1) [3-15].

Because different demographic characteristics and HCC detection rate might affect incidence of HBV-related HCC, we confined our analysis to young age group ( 40 to 49 years). Not only incidence but mortality from HBV-related HCC was investigated. The incidence was 495 and 155 per 100,000 persons with HBV infection in Korea and Taiwan, respectively. The mortality was also largely different, 434 and 136 per 100,000 persons with HBV infection in Korea and Taiwan, respectively.

This marked difference in HCC incidence prompted us to conduct an identical analysis among hepatitis $\mathrm{C}$ virus (HCV)-positive patients (Supplementary Table 2) [2,10-12,14,16-18]. Population data, prevalence of chronic hepatitis $\mathrm{C}$, and annual number of HCV-related HCC cases (40 to 79 years of age) were acquired from publicly available data. Interestingly, the annual incidence of HCV-related HCC was similar in the two countries: 570 and 519 per 100,000 persons with HCV infection in Korea and Taiwan, respectively (Fig. 1). Based on this finding, we postulate that viral factors, rather than host or environ- 


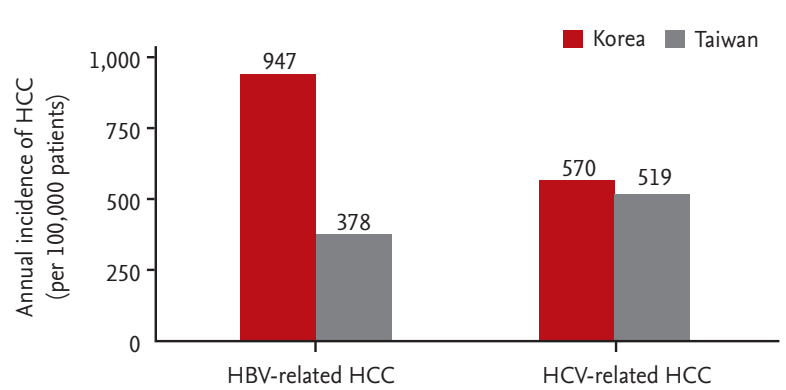

Figure 1. Annual incidence of hepatocellular carcinoma (HCC) in patients with chronic viral hepatitis B or C. Data were obtained from national cancer reports and large-scale prevalence studies of viral hepatitis in Korea and Taiwan. The annual incidence of hepatitis B virus (HBV) (or hepatitis $\mathrm{C}$ virus [HCV]) -related HCC per 100,000 persons with HBV (or $\mathrm{HCV}$ ) infection is shown.

mental factors, may play a major role in the marked difference in development of HBV-related HCC between the two countries.

The majority of Asians infected with HBV have genotype $\mathrm{B}$ or $\mathrm{C}$ virus, which is associated with vertical transmission. Korea is a racially homogenous country in which all HBVs are genotype $\mathrm{C}$, whereas genotype $\mathrm{B}$ is the most prevalent in Taiwan [19]. Genotype C HBV is associated with higher serum viral load, delayed hepatitis $\mathrm{B}$ e antigen seroconversion, and a higher risk of disease progression to liver cirrhosis or HCC than those of the other genotypes $[20,21]$. Although unknown host or environmental factors may exist, viral factors, particularly genotype $\mathrm{C}$ virus, might have a critical role in HCC development among Korean patients.

\section{Conflict of interest}

No potential conflict of interest relevant to this article was reported.

\section{REFERENCES}

1. El-Serag HB, Rudolph KL. Hepatocellular carcinoma: epidemiology and molecular carcinogenesis. Gastroenterology 2007;132:2557-2576.

2. de Martel C, Maucort-Boulch D, Plummer M, Franceschi S. World-wide relative contribution of hepatitis B and $\mathrm{C}$ viruses in hepatocellular carcinoma. Hepatology 2015;62:1190-1200.
3. Ministry for Health, Welfare and Family Affairs. Annual report of cancer incidence (2005) and survival (1993-2005) in Korea [Internet]. Seoul (KR): Ministry for Health, Welfare and Family Affairs, 2008 [cited 2017 Jun 28]. Available from: http://ncc.re.kr/cancerStatsList.ncc?searchKey=total\&searchValue=\&pageNum=1.

4. Ministry for Health, Welfare and Family Affairs. Annual report of cancer incidence (2007), cancer prevalence (2007) and survival (1993-2007) in Korea [Internet]. Seoul (KR): Ministry for Health, Welfare and Family Affairs, 2009 [cited 2017 Jun 28]. Available from: http://ncc. re.kr/cancerStatsList.ncc?searchKey=total\&searchValue=\&pageNum $=1$.

5. Ministry of Health and Welfare; Korea Central Cancer Registry; National Cancer Center. Annual report of cancer statistics in Korea in 2008 [Internet]. Goyang(KR): National Cancer Center, 2010 [cited 2017 Jun 28]. Available from: http://ncc.re.kr/cancerStatsView.ncc?bbsnum $=189 \&-$ searchKey=total\&searchValue=\&pageNum=2.

6. Ministry of Health and Welfare; Korea Central Cancer Registry; National Cancer Center. Annual report of cancer statistics in Korea in 2009 [Internet]. Goyang(KR): National Cancer Center, 2011 [cited 2017 Jun 28]. Available from: http://ncc.re.kr/cancerStatsView.ncc?bbsnum=229\&searchKey=total\&searchValue=\&pageNum=2.

7. Ministry of Health and Welfare; Korea Central Cancer Registry; National Cancer Center. Annual report of cancer statistics in Korea in 2010 [Internet]. Goyang (KR): National Cancer Center, 2012 [cited 2017 Jun 28]. Available from: http://ncc.re.kr/cancerStatsView.ncc?bbsnum=250\&searchKey=total\&searchValue=\&pageNum=1.

8. Ministry of Health and Welfare; Korea Central Cancer Registry; National Cancer Center. Annual report of cancer statistics in Korea in 2011 [Internet]. Goyang (KR): National Cancer Center, 2013 [cited 2017 Jun 28]. Available from: http://ncc.re.kr/cancerStatsView.ncc?bbsnum=295\&searchKey=total\&searchValue=\&pageNum=1.

9. Kim H, Shin AR, Chung HH, et al. Recent trends in hepatitis B virus infection in the general Korean population. Korean J Intern Med 2013;28:413-419.

10. Park JW, Kim CM. Epidemiology of hepatocellular carcinoma in Korea. Korean J Hepatol 2005;11:303-310.

11. Kim KS, Kim SH, Kim IH, et al. Report of Primary Liver Cancer Randomised Registration in Korea. Seoul (KR): The Korean Liver Cancer Study Group, National Cancer Registration Center, 2010. 
12. National Statistics Republic of China (Taiwan). Statistical yearbook of the Republic of China 2014 [Internet]. Taipei City (TW): National Statistics Republic of China (Taiwan) [cited 2017 Jun 28]. Available from: http://eng.stat.gov.tw/ lp.asp? ctNode $=2265 \& \mathrm{CtUnit}=1072 \&$ BaseDSD $=36$.

13. Chen CL, Yang JY, Lin SF, et al. Slow decline of hepatitis B burden in general population: results from a population-based survey and longitudinal follow-up study in Taiwan. J Hepatol 2015;63:354-363.

14. Health Promotion Administration, Ministry of Health and Welfare. Cancer Registry Annual Report (2002). Taipei City (TW): Ministry of Health and Welfare, 2006.

15. Chen CH, Su WW, Yang SS, et al. Long-term trends and geographic variations in the survival of patients with hepatocellular carcinoma: analysis of 11,312 patients in Taiwan. J Gastroenterol Hepatol 2006;21:1561-1566.

16. Ministry of Health and Welfare; Korea Central Cancer Registry; National Cancer Center. Annual report of cancer statistics in Korea in 2012 [Internet]. Goyang (KR): National Cancer Center, 2014 [cited 2017 Jun 28]. Available from: http://ncc.re.kr/cancerStatsView.ncc?bbsnum=316\&searchKey=total\&searchValue=\&pageNum=1.
17. Korea Centers for Disease Control and Prevention. The fifth Korea National Health and Nutrition Examination Survey (KNHANES V-3), 2012 [Internet]. Cheongju (KR): Korea Centers for Disease Control and Prevention, c2012 [cited 2017Jun 28]. Available from:http://cdc.go.kr/CDC/contents/ CdcKrContentView.jsp?cid=60939\&menuIds=HOMEoo1MNU1130-MNU1639-MNU1748-MNU1751.

18. Chen CH, Yang PM, Huang GT, Lee HS, Sung JL, Sheu JC. Estimation of seroprevalence of hepatitis B virus and hepatitis $\mathrm{C}$ virus in Taiwan from a large-scale survey of free hepatitis screening participants. J Formos Med Assoc 2007;106:148-155.

19. Sunbul M. Hepatitis B virus genotypes: global distribution and clinical importance. World J Gastroenterol 2014;20:5427-5434.

20. Livingston SE, Simonetti JP, Bulkow LR, et al. Clearance of hepatitis $\mathrm{B}$ e antigen in patients with chronic hepatitis B and genotypes A, B, C, D, and F. Gastroenterology 2007;133:1452-1457.

21. Wong GL, Chan HL, Yiu KK, et al. Meta-analysis: the association of hepatitis B virus genotypes and hepatocellular carcinoma. Aliment Pharmacol Ther 2013;37:517-526. 
Supplementary Table 1. Annual incidence of HBV-related HCC among HBsAg positive persons in Korea and Taiwan

\begin{tabular}{|c|c|c|c|c|c|c|c|}
\hline \multirow[t]{8}{*}{ Korea } & Year & 2005 & 2007 & 2008 & 2009 & 2010 & 2011 \\
\hline & Population (40-79 years) [3-8] & $18,969,207$ & $20,134,718$ & $20,773,695$ & $21,436,385$ & $22,071,724$ & $22,706,738$ \\
\hline & HBsAg prevalence, \% [9] & 4.21 & $4 \cdot 58$ & $4 \cdot 31$ & 3.88 & 3.68 & 4.20 \\
\hline & $\mathrm{HBV}(+)$ population & 798,125 & 922,191 & 896,258 & 831,270 & 812,725 & 952,891 \\
\hline & Liver cancer [3-8] & 13,509 & 13,454 & 14,117 & 14,387 & 14,279 & 14,687 \\
\hline & $\operatorname{HCC}[10]$ & 10,456 & 10,413 & 10,927 & 11,136 & 11,052 & 11,368 \\
\hline & HBV-related HCC [11] & 7,560 & 7,529 & 7,900 & 8,051 & 7,991 & 8,219 \\
\hline & $\begin{array}{l}\text { Incidence of HBV-related } \\
\mathrm{HCC} \text { (per 100,000 HBsAg } \\
\text { positive persons) }\end{array}$ & $947 \cdot 2$ & 816.4 & 881.4 & 968.5 & 983.2 & 862.5 \\
\hline \multirow[t]{8}{*}{ Taiwan } & Year & 2002 & & & & & \\
\hline & Population (40-79 years) [12] & $8,265,666$ & & & & & \\
\hline & HBsAg prevalence, \% [13] & 13.27 & & & & & \\
\hline & $\mathrm{HBV}(+)$ population & $1,096,944$ & & & & & \\
\hline & Liver cancer $[14]$ & 7,630 & & & & & \\
\hline & $\operatorname{HCC}[14]$ & 6,390 & & & & & \\
\hline & HBV-related HCC [15] & 4,147 & & & & & \\
\hline & $\begin{array}{l}\text { Incidence of HBV-related } \\
\mathrm{HCC} \text { (per 100,000 HBsAg } \\
\text { positive persons) }\end{array}$ & 378.1 & & & & & \\
\hline
\end{tabular}

HBV, hepatitis B virus; HCC, hepatocellular carcinoma; HBsAg, hepatitis B surface antigen. 
Supplementary Table 2. Annual incidence of HCV-related HCC among HCV-positive persons in Korea and Taiwan

\begin{tabular}{|c|c|c|}
\hline \multirow[t]{8}{*}{ Korea } & Year & 2012 \\
\hline & Population (40-79 years) [16] & $23,313,951$ \\
\hline & Anti-HCV(+) prevalence, $\%[17]$ & 0.94 \\
\hline & $\mathrm{HCV}(+)$ population & 220,298 \\
\hline & Liver cancer $[16]$ & 14,485 \\
\hline & $\mathrm{HCC}[10]$ & 11,211 \\
\hline & HCV-related HCC [11] & 1,256 \\
\hline & Incidence of HCV-related HCC (per 100,000 HCV positive persons) & 570.0 \\
\hline \multirow[t]{8}{*}{ Taiwan } & Year & 2002 \\
\hline & Population (40-79 years) [12] & $8,265,666$ \\
\hline & Anti-HCV(+) prevalence, \% [18] & 4.18 \\
\hline & $\mathrm{HCV}(+)$ population & 345,755 \\
\hline & Liver cancer $[14]$ & 7,630 \\
\hline & $\mathrm{HCC}[14]$ & 6,390 \\
\hline & HCV-related HCC [2] & 1,796 \\
\hline & Incidence of HCV-related HCC (per 100,000 HCV positive persons) & $519 \cdot 3$ \\
\hline
\end{tabular}

HCV, hepatitis C virus; HCC, hepatocellular carcinoma. 